\title{
Announcements/Chronique
}

TEACHING PHILOSOPHY

Do you remember those first two fantastic National Workshop-Conferences on Teaching Philosophy? There's going to be another one! And this time, it will include the first national meeting of the American Association of Philosophy Teachers. AAPT and the biennial workshop-conferences are spearheading a sustained national effort to support and improve the teaching of philosophy in all its settings and forms. The Third National Workshop-Conference at the University of Toledo, August $12-15,1980$, will bring together in one place the people and programs that are leading the way. They will focus upon new methods, materials and areas of philosophy teaching, plus the likely impact of these upon the future of philosophy. The primary activity of participants will be active involvement in workshop discussions with fellow teachers.

Conference applications and detailed descriptions of planned workshops will be mailed in January 1980 . To be put on the mailing list, write to: Professor Richard A. Wright, Chair, Program Committee, 3rd NW-CTP, Department of Philosophy, University of Toledo, Toledo, $\mathrm{OH} 43606$.

\section{CONFERENCE ON MARX}

The Department of Philosophy of the University of Victoria, in cooperation with the Department of Philosophy of Simon Fraser University, wishes to announce a conference on Marx to be held at the University of Victoria from the evening of Friday, 24 October 1980 , until the afternoon of Sunday, 26 October 1980.

The programme to date comprises papers by:

Gerald A. Cohen, University of London. (Author of Karl Marx's Theory of History: A Defense.) 


\section{I82 Announcements/Chronique}

John McMurtry, University of Guelph. (Author of The Structure of Marx's World View.)

Melvin Rader, University of Washington. (Author of Marx's Interpretation of History.)

Irving Zeitlin, University of Toronto. (Author of Marxism: A Re-examination, and Ideology and The Development of Sociological Theory.)

A further one, or two, paper(s) will be read.

Complete and final details of the conference will be announced later. Inquiries may be addressed to the Department of Philosophy, University of Victoria, P.O. Box 1700 , Victoria, B.C. V8W $2 \mathrm{Y}_{2}$.

\section{NEWS RELEASE}

The Philosophy Documentation Center will undertake the publication and distribution of the journal Teaching Philosophy beginning with Volume 3 (1979-80). The journal will continue as a semi-annual until 198I when it will begin a quarterly schedule with Volume 4. Subscription and advertising correspondence should be addressed to the Philosophy Documentation Center, Bowling Green State University, Bowling Green, Ohio 43403 U.S.A.

This will mean no change for the editorial functions of the journal, which will remain with Arnold Wilson, Editor, Teaching Philosophy 206 University of Cincinnati, Cincinnati, Ohio 4522 I U.S.A. 